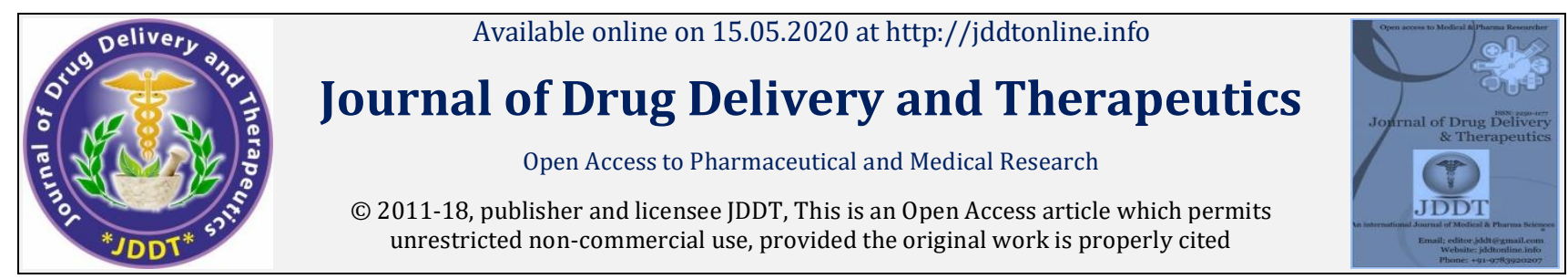

Open $\odot$ Access

Review Article

\title{
SARS - COV-2 (COVID-19) Pandemic: A Critical Review on Novel Coronavirus Pathogenesis, Clinical Diagnosis and Treatment
}

\author{
Ruchi Jain', Nilesh Jain ${ }^{2 *}$ and Surendra Kumar Jain'1, Ram C Dhakar ${ }^{3}$ \\ ${ }^{1}$ Sagar Institute of Research \& Technology-Pharmacy, Ayodhya Bypass Road, Bhopal, Madhya Pradesh, India - 462041 \\ 2* Sagar Institute of Research Technology \& Science-Pharmacy, Ayodhya Bypass Road, Bhopal, Madhya Pradesh, India - 462041 \\ ${ }^{3}$ SRG Hospital \& Medical College, Jhalawar, Rajasthan, India-326001
}

\begin{abstract}
The 2019-nCoV is officially called SARS-CoV-2 and the disease is named COVID-19. The Novel coronavirus (SARS-CoV-2) caused pneumonia in Wuhan, China in December 2019 is a highly contagious disease. The World Health Organization (WHO) has declared it as a global public health emergency. This is the third serious Coronavirus outbreak in less than 20 years, following SARS in 2002-2003 and MERS in 2012 . Currently, the research on novel coronavirus is still in the primary stage. It is currently believed that this deadly Coronavirus strain originated from wild animals at the Huanan market in Wuhan by Bats, snakes and pangolins have been cited as potential carriers. On the basis of current published evidence, we systematically summarize the epidemiology, clinical characteristics, diagnosis, treatment and prevention of COVID-19. This review in the hope of helping the public effectively recognize and deal with the novel coronavirus (SARS-CoV-2) and providing a reference for future studies.
\end{abstract}

Keywords: SARS-CoV-2, COVID-19, Coronavirus, pneumonia, Respiratory infection

Article Info: Received 28 March 2020; $\quad$ Review Completed 24 April 2020; $\quad$ Accepted 29 April 2020; $\quad$ Available online 15 May 2020

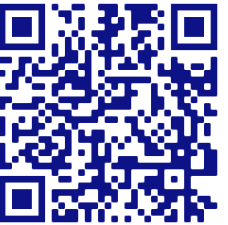

Cite this article as:

Jain R, Jain N, Jain SK, Dhakar RC, SARS - COV-2 (COVID-19) Pandemic: A Critical Review on Novel Coronavirus Pathogenesis, Clinical Diagnosis and Treatment, Journal of Drug Delivery and Therapeutics. 2020; 10(3):241-252 http://dx.doi.org/10.22270/jddt.v10i3.3985

Dr. Nilesh Jain, Professor, Sagar Institute of Research Technology \& Science-Pharmacy, Ayodhya Bypass Road, Bhopal - 462041. Tel: (91) 9425074520; E-mail: prof.nileshjain@gmail.com

\section{Introduction}

There is a current worldwide outbreak of the novel coronavirus Covid-19 (coronavirus disease 2019; the pathogen called SARS-CoV-2; previously 2019-nCoV), which originated from Wuhan in China and has now spread to 7 continents including 102 countries. Governments show their concern to stop the outbreak spreading into a global health emergency. Coronaviruses, a large family of single-stranded RNA viruses, can infect animals and also humans, causing respiratory, gastrointestinal, hepatic, and neurologic diseases $^{1}$. As the largest known RNA viruses, CoVs are further divided into four generation: alpha-coronavirus, beta- coronavirus, gamma-coronavirus and deltacoronavirus $^{2}$. Now days there are six human coronaviruses (HCoVs) has been identified, including the alpha-CoVs HCoVs-NL63 and HCoVs-229E and the beta-CoVs HCoVsOC43, HCoVs-HKU1, severe acute respiratory syndrome-CoV $(\mathrm{SARS}-\mathrm{CoV})^{3}$, and Middle East respiratory syndrome-CoV $(\mathrm{MERS}-\mathrm{CoV})^{4}$. New coronaviruses appear to emerge periodically in humans, mainly due to the high prevalence and wide distribution of coronaviruses, the large genetic diversity and frequent recombination of their genomes, and the increasing of the human-animal interface activities $5,6$.

\section{Structure and genomes of Coronavirus}

Coronaviruses (CoVs) have crown-like spikes on their surface and belong to the family Coronaviridae within the order Nidovirales. Corona viruses broadly infect vertebrates including humans, birds, bats, snakes, mice and other wild animals ${ }^{7}$. Corona viruses (HCoVs) have been identified since mid-1960s ${ }^{8,9}$. Four commonly detected HCoVs are 229E, 0C43, NL63 and HKU1. In one study, 229E and OC43 accounted for approximately $15-29 \%$ of respiratory pathogens with relatively low virulence in humans ${ }^{10}$. Another epidemiological study in adults estimates that coronavirus causes about $15 \%$ of common colds ${ }^{11}$. Other significant causes of upper respiratory infections include influenza virus, rhinovirus, parainfluenza virus, Group A Streptococci, EBV and respiratory syncytial virus (RSV).

The three other strains of HCoVs, severe acute respiratory syndrome coronavirus (SARS-CoV), Middle East respiratory syndrome coronavirus (MERS-CoV), and severe acute respiratory syndrome coronavirus 2 (SARS-CoV-2), have a different pathogenicity and lead to higher mortality rates in human populations. MERS-CoV was isolated from a male patient who died from acute pneumonia and renal failure in Saudi Arabia in 201212. 
CoVs is the largest known genome among RNA viruses contains an envelope with a non-segmented, positive-sense, single-strand RNA, with size ranging from 26,000 to 37,000 bases ${ }^{13}$. All coronavirus genomes are arranged similarly with the replicase locus encoded within the $5^{\prime}$ end and the structural proteins encoded in the 3' third of the genome arranged in the order hemagglutinin esterase (HE), if present (HE is only present in some beta coronaviruses), spike (S), small membrane (E), membrane (M) and nucleocapsid (N) and internal (I) protein, encoded within the $\mathrm{N}$ gene. The nucleo capsid protein complexes with the genome RNA to form a helical capsid structure found within the viral envelope. Trimers of the spike protein form the peplomers embedded in the envelope giving the virion its corona or crown-like morphology. In some coronavirus virions, the HE protein forms smaller spikes on the membrane. $\mathrm{M}$ and $\mathrm{E}$ are also transmembrane proteins involved in virus assembly ${ }^{1}$.Fig. 1

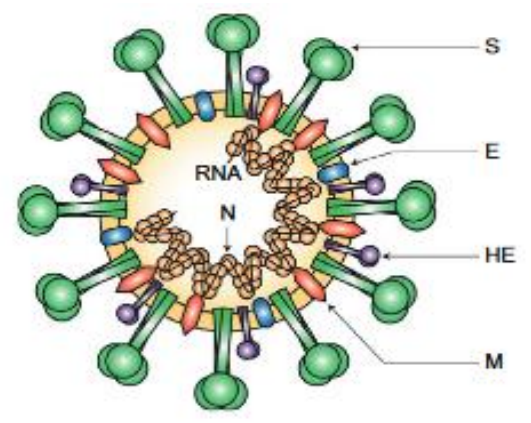

Fig.1: Coronavirus virion structure.

\section{Genetic Diversity}

The genome RNA shown in fig.2 is complexed with the $\mathrm{N}$ protein to form a helical cased within the viral membrane, HE, hemagglutinin-esterase; S, spike; E, small membrane envelope; $M$, membrane are all transmembrane proteins. The genomic structure of SARS-CoV-2 is 5'-UTR-orf1a-orf1ab-S (Spike)-E (Envelope)-M (Membrane)-N (Nucleocapsid)$3^{\prime}$ UTRpoly (A) tail. Accessory genes are interspersed within the structural genes at the $3^{\prime}$ end of genome. The pp1a protein encoded by the orf1a gene and the pp1ab protein encoded by the orf1ab gene contains 10 nsps (nsp1-nsp10). The pp1ab protein also includes nsp12-nsp16.

The various CoVs of animal origin undergo evolution and genetic recombination, thereby resulting in mutated CoVs that may be highly pathogenic and potentially be more deadly to humans ${ }^{15}$. The mutation rate in the SARS-CoV genome was estimated to be $0.80-2.38 \times 10^{-3}$ nucleotide substitutions per site per year, which are similar to that of other RNA viruses ${ }^{16}$. The various CoVs of animal origin undergo evolution and genetic recombination either within the host species or upon jumping from one species to another. Such changes thus have the potential to lead to variants that have high pathogenic potential when transmitted to humans ${ }^{17-19}$. Recently, two mutations of the S protein and $\mathrm{N}$ protein SARS-CoV-2 may explain its zoonotic transmission 20 . Genomic alignment of 54 SARS-CoV-2 genomes identified two hotspots of hypervariability at positions 8789 (synonymous variant) and 28,151(Ser/Leu change), located in the polyprotein and ORF8 genes respectively 21 .

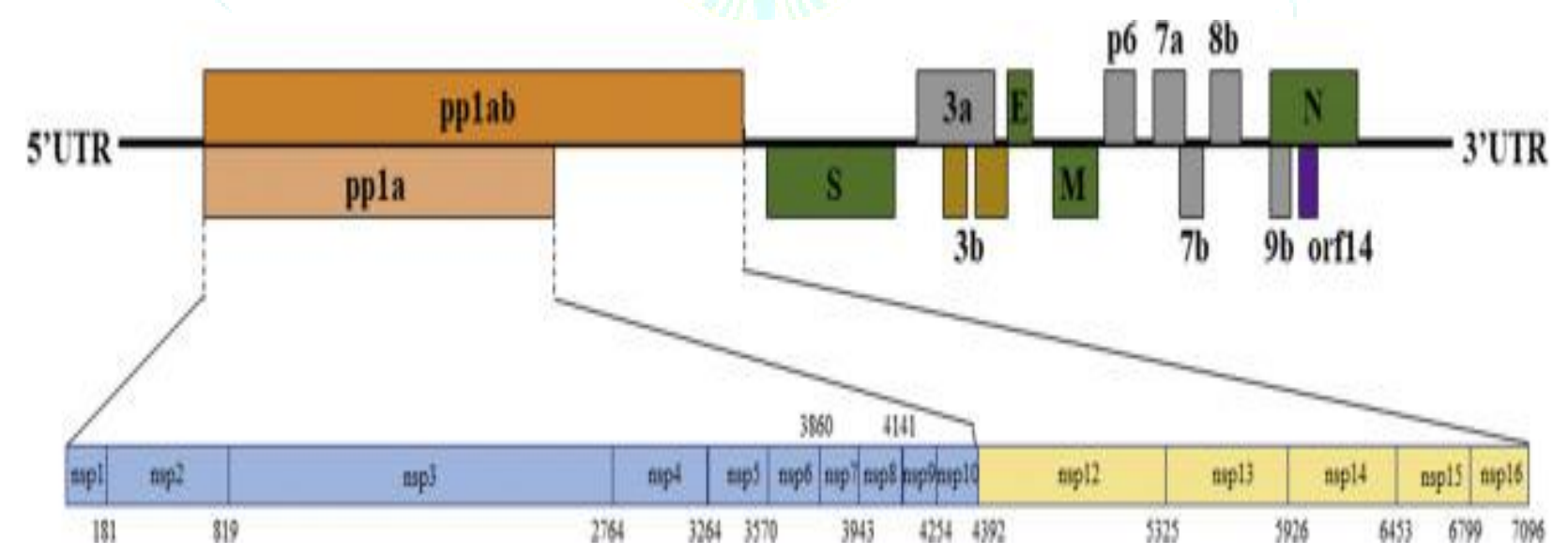

Fig. 2: Schematic diagram of the SARS-CoV-2 genome14.

\section{Mode of Transmission of Coronavirus}

SARS-CoV originated from bats of the Hipposideridae family before dissemination to humans ${ }^{22}$. CoVs can transmit across species barriers. The earliest patients infected with SARSCoV-2 in Wuhan ultimately caused the epidemic known as CoronaVirus Disease 2019 (COVID-2019) ${ }^{23}$. Some of these patients had a history of contact with a wholesale seafood market in the early stages, suggesting animal-to-person spread. Subsequently, a large number of patients reportedly did not have exposure to the markets, suggesting the development of person-to-person 24-27.

There are three ways to transmit the virus, including 28-30:

1. Close person-to-person contact

2. Aerosol transmission

\section{Transmission by touch}

It also thought that the virus to be transmitted to other people by ${ }^{31}$

A respiratory droplet means coughing or sneezing. Droplet spread can occur when an infected person sneezes or coughs, whereupon virus containing droplets are propelled up to 3 feet through the air and are deposited on the mucous membranes of the mouth, nose, or eyes of persons who are nearby.

1. Transmission through the ocular surface is also possible.

2. Shaking hands with an infected person,

3. Touching an infected object/surface, 
4. Frequent touching of the nose or mouth or coming into contact with a patient's excreta.

5. Another way is through "hidden transmission", in which asymptomatic infected individuals or carriers unknowingly transmit the virus to unsuspecting contacts.

\section{The pathogenesis of COVID-19}

Current understanding of the pathogenesis of HCoVs infection is still limited, especially for SARS-CoV-2. Before 2019, there were six CoVs that could infect humans and cause respiratory disease. $\mathrm{HCoV}-229 \mathrm{E}, \mathrm{HCoV}-\mathrm{OC} 43, \mathrm{HCoV}-$ NL63 and HCoV-HKU1 are sometimes attributed to the "common cold", but in rare cases can cause severe infections in infants, young children and elderly people. On the other hand, SARS-CoV and MERS-CoV can infect the lower respiratory tract and cause a severe respiratory syndrome in human. The new coronavirus SARS-CoV-2 is similar to SARS$\mathrm{CoV}$ and MERS-CoV and can infect lower respiratory tract and cause severe pneumonia.

The origin of SARS-CoV-2 was thought to be wild animals in the Huanan Seafood Market in Wuhan. However, not all cases have an apparent connection with the Wuhan Huanan
Seafood Wholesale Market. It is evident now that SARS-CoV2 is capable of person-person transmission. We list the major pathogenic CoVs in Table 1 for better understanding of the pathogenesis of $\mathrm{HCoV}^{32}$.

The term "cell pyroptosis" was first proposed in 200133. In recent decades, there has been increasing evidence suggesting that "pyroptosis" is a novel inflammatory form of programmed cell death. In 2019, Chen et al. found that SARSCoV Viroporin 3a triggered the activation of the NLRP3 inflammasome and the secretion of IL-1 $\beta$ in bone marrowderived macrophages, suggesting SARS-CoV induced cell pyroptosis $^{34}$ The pathways involved in the activation of the signaling between NLRP3m IL-1 $\beta$, IL-18 and GSDMD are illustrated in Fig. 3 and are a subject of study in samples from SARS-CoV-2 patients ${ }^{35}$.

The COVID-19 may be linked to cell pyroptosis, especially in lymphocytes through the activation of the NLRP3 inflammasome. Morphological changes in lymphocytes and macrophages, nucleic acid and protein levels in classical and non-classical cells, detection of NLRP3 and GSDMD, and the role of inflammatory cytokines IL-1 $\beta$ and IL-18 requires further research.

Table 1: Partial list of important pathogenic human coronaviruses

\begin{tabular}{lll}
\hline Virus & Genus & Symptoms \\
\hline HCoV-229E & alpha & mild respiratory tract infections \\
HCoV-NL63 & alpha & mild respiratory tract infections \\
HCoV-OC43 & beta & mild respiratory tract infections \\
HCoV-HKU1 & beta & pneumonia \\
SARS-CoV & beta & severe acute respiratory syndrome, 11\% mortality rate \\
MERS-CoV & beta & severe acute respiratory syndrome, 34\% mortality rate \\
SARS-CoV-2 & beta & severe acute respiratory syndrome, 2.6\% mortality rate \\
\hline
\end{tabular}

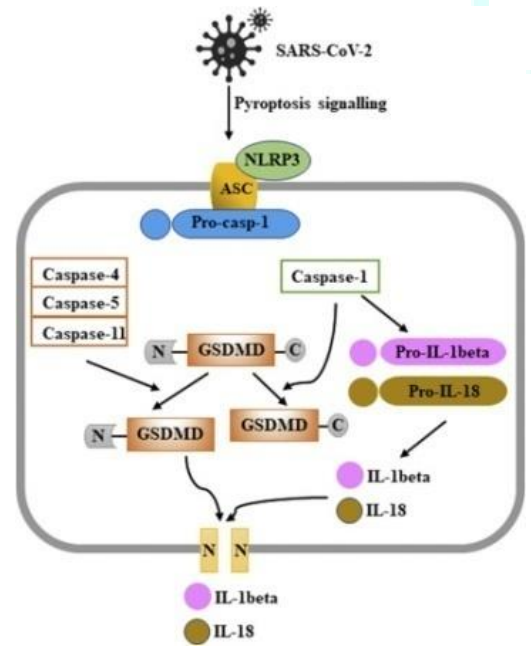

Fig. 3: A hypothesis of the relationship between SARSCoV-2 and cell pyroptosis

\section{Clinical Manifestation}

The patients with SARS-CoV-2 shows a wide range of clinical manifestations are seen in from mild, moderate, to severe and rapidly progressive. Most of the patients with SARS-CoV-
2 were normal and mild, and their mortality was lower than SARS-CoV and MERS-CoV.

5.1 Transmission: person-to-person, primarily via respiratory droplets (sneezing and coughing)

- Direct contact transmission: especially hand-to-face contact

- Fomite transmission: not documented but conceivably possible, especially with objects and surfaces that may have recently come into contact with infected individuals

- Transmission via mail and packaged (imported) goods: There is no evidence to suggest that mail and packaged (imported) goods pose a risk for the spread of COVID19.

- Fecal-oral transmission: Evidence that both SARS-CoV and MERS-CoV are excreted fecally suggests that fecaloral transmission is possible ${ }^{36}$.

\subsection{Incubation Period}

The mean incubation period of CoVID-19 was a little bit different. The study with 138 patients, reported that the median durations from first symptoms to dyspnea, hospital admission, and Acute severe respiratory syndrome (ARDS) 
were 5 days (range, 1-10), 7 days (range, 4-8), and 8 days (range, 6-12), respectively37. The mean time from symptom onset to hospitalization was between 2 and 8 days, but was shorter toward the later phase of the epidemic. The mean time from symptom onset to need for invasive mechanical ventilation (IMV) and to death was 11 and 23.7 days, respectively 38 .

\subsection{Symptom of CoVID-19}

Symptom of CoVID-19 can range from no symptoms (asymptomatic) to severe pneumonia and death. The patients were initially diagnosed with the outbreak found that the most common symptoms were fever (98\%), cough $(76 \%)$, myalgia or fatigue (44\%), and atypical symptoms included sputum (28\%), headache (8\%), hemoptysis $(5 \%)$ and diarrhea (3\%). About half of the patients had dyspnea (the median from onset to dyspnea was 8 days). Lymphocytopenia was observed in $63 \%$ of patients. All patients had pneumonia.

Complications included acute respiratory distress syndrome (29\%), acute heart injury (12\%), and secondary infections (10\%); $32 \%$ of patients require to be treated in the ICU 39 The patients presented ground-glass shadow on chest CT. Recent studies indicate that patients $\geq 60$ years of age are at higher risk than children who might be less likely to become infected or, if so, may show milder symptoms or even asymptomatic infection 40 .

Before the first outbreak of SARS, a limited number of HCoVs such as HCoV-229E were frequently found to infect humans, and were widely circulating in human populations causing only mild illnesses like the common cold. However, SARS, MERS and SARS-CoV-2 present with a spectrum of disease severity ranging from flu-like symptoms to acute respiratory distress syndrome ${ }^{41,42}$.

\section{Early Detection and Diagnosis}

The SARS-CoV-2 infected cases have symptoms like fever, fatigue, dry cough, dyspnea etc., with or without nasal congestion, runny nose or other upper respiratory symptoms. Early identification of suspect cases is the key to inhibiting the spread of the virus. Rapid identification of the viral genome and the development of rapid diagnostic tests will facilitate the isolation of those who are confirmed as infected 43

\section{Diagnostic criteria ${ }^{44-50}$}

The diagnostic criteria of suspected and confirmed cases were summarized in Table 2 .

Table 2. The diagnostic criteria for suspected and confirmed cases

Case
Siagnostic criteria
Anyone with a history of epidemiology and any two of the clinical manifestations or anyone without
epidemiological history and three of the clinical manifestations is considered to be a suspected case:
(1) Epidemiological history:
1) within 14 days before the disease onset, there is a travel history or living history in Wuhan or other
areas with local cases
2) within 14 days before the disease onset, there is contact with patients who had fever or respiratory
symptoms from Wuhan or other areas with local cases
3) a clustering of patients or a contact with patients infected with the SARS-CoV-2
(2) Clinical manifestations:
1) fever and/or respiratory symptoms
2) with the above-mentioned imaging characteristics of pneumonia
3) the total number of leukocytes in the early stage of the disease is normal or decreased, or the
lymphocyte count is decreased
Any suspected case with one of the following pathogenic features is reclassified as a confirmed case:
(1) Positive results of SARS-CoV-2 nucleic acids by RT-PCR* of respiratory or blood specimens
(2) DNA highly homologous to SARS-CoV-2 by genetic sequencing of viral genes in respiratory or blood
specimens

*RT-PCR: real-time reverse-transcriptase polymerase-chain-reaction.

\subsection{Physical examination}

Patients with mild symptoms may not be present positive signs. Patients in severe condition may have shortness of breath, moist rales in lungs, weakened breath sounds, dullness in percussion, and increased or decreased tactile speech tremor, etc.

\subsection{CT imaging examination}

The imaging finding vary with the patient's age, immunity status, disease stage at the time of scanning, underlying diseases, and drug interventions. Chest $X$-ray examination In the early stage of pneumonia cases, chest images show multiple small patchy shadows and interstitial changes 51 , Severe cases can further develop to bilateral multiple ground-glass opacity, infiltrating shadows, and pulmonary consolidation, with infrequent pleural effusion.

\subsection{Laboratory Diagnosis}

Laboratory diagnosis mainly used to distinguished from other known viral virus of pneumonia, such as parainfluenza virus, influenza viruses, respiratory syncytial virus, rhinovirus, SARS-CoV,adenovirus, etc.; and also, from chlamydia pneumonia, mycoplasma pneumonia, and bacterial pneumonia. In addition, it should be distinguished 
from non-infectious diseases, such as dermatomyositis,vasculitis, and organizing pneumonia ${ }^{52}$. So, laboratory diagnosis is necessary. Identification of CoVID-19 mainly includes virus isolation and viral nucleic acid detection. A variety of specimens (such as swabs, nasal swabs, nasopharynx or trachea extracts, sputum or lung tissue, blood and feces) were used for testing in timely manner, which gives a higher rate of positive detection of lower respiratory tract specimens ${ }^{53}$. The Patients suspected SARS-CoV-2 infection for diagnosis by real time RT-PCR method 54 .

\section{Prevention and Treatment of SARS-CoV-2 infection}

Novel coronavirus infection is a new communicable disease which affects almost all populations with all age group 55 .
SARS-CoV-2 infection has been classified as category B infectious disease legally but managed as category A infectious disease by Chinese government. It is paramount to implement infection control practices by infection source controlling, transmission route blocking, and susceptible population protection. The unprecedented flurry of activity by WHO and other global public health bodies has mainly focused on preventing transmission, infection control measures, and screening of travelers ${ }^{56}$.

There is no clear, unified and effective treatment plan for COVID-19. Most guidelines emphasize early identification, early isolation, early diagnosis, and early treatment. The treatment and management of SARS-CoV-2 pneumonia mainly include the following aspects 57-61 Fig. 4.

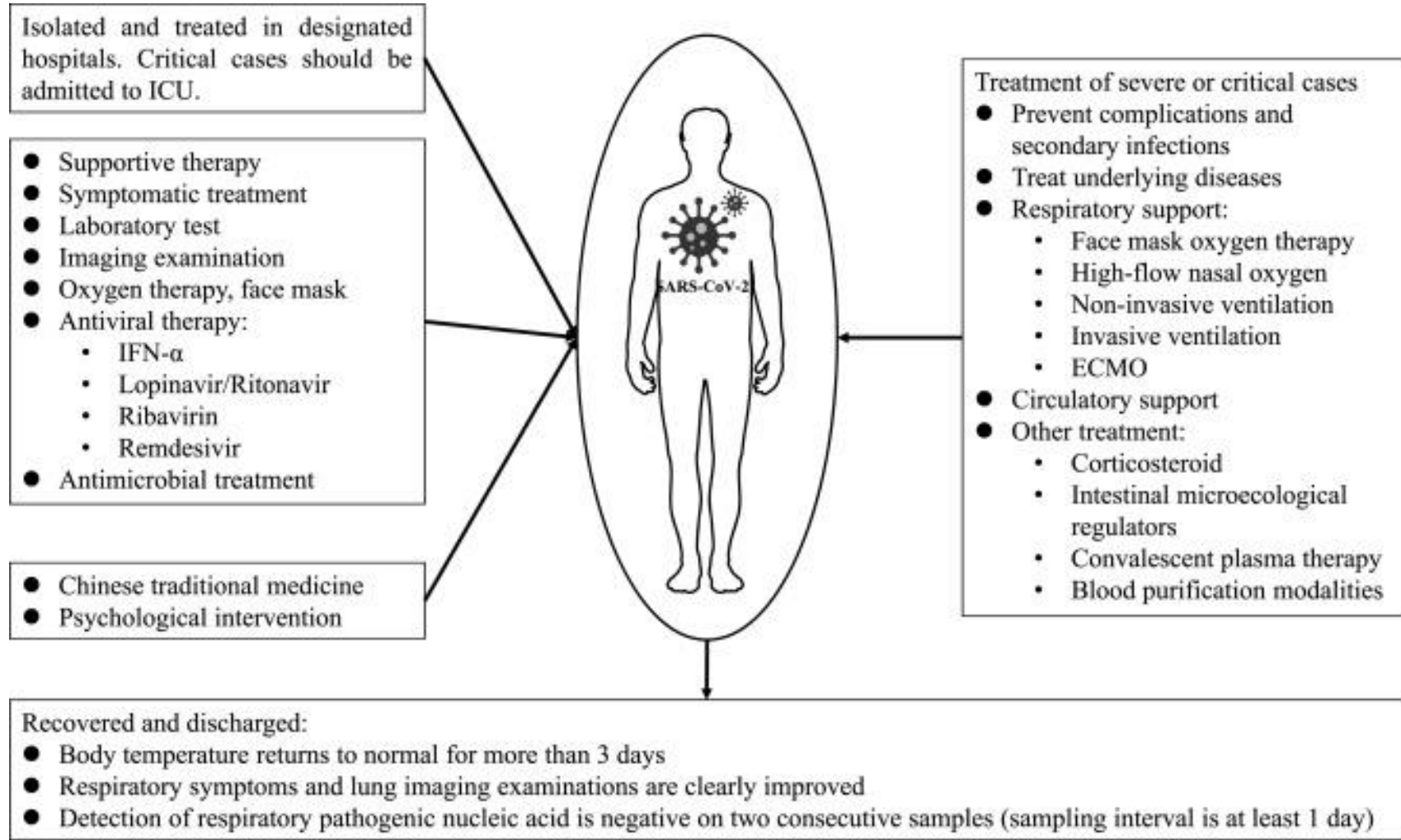

Fig. 4. The treatment and management of COVID-19 pneumonia. ICU: intensive care unit; ECMO: extracorporeal membrane oxygenation

\subsection{General protective measures}

\section{Hand hygiene:}

- Hands should be washed with soap and water or disinfected with a virucidal hand disinfectant after contact with potentially virus-contaminated objects and infected persons

- $\quad$ Avoid touching the face: i.e., the eyes, nose, and mouth.

\section{Respiratory hygiene and cough etiquette}

- Avoid coughing or sneezing in the direction of others!

- Use tissues and discard these after use.

- If tissues are unavailable, coughing and sneezing into the crook of the arm can help keep hands free of contamination.
- Maintain 3-6 ft (at least an arm's length) distance to coughing or sneezing persons.

\section{Avoid exposure}

- Avoid crowds of people (public transport, train stations, airports, mass events)

- $\quad$ Avoid travel to areas of outbreak.

\section{Masks}

- In individuals with confirmed and suspected infection: useful for preventing the diffusion of respiratory secretions, e.g., during patient transports

- In healthcare facilities (HCFs) or home care settings: crucial for health workers and persons taking care of an infected individual in close settings (in a HCF or at home) 
- $\quad$ Surgical masks do not provide adequate protection in the setting of invasive diagnostics or those at high risk of exposure.

- N95 respirators and protective eyewear are recommended for health care personnel that are potentially exposed to airborne and fluid hazards (e.g., during invasive procedures).

- Confirmed COVID-19 patients and PUIs can use standard $\mathrm{N} 95$ respirators.

- If N95 respirator bottlenecks occur, unvalved N95 respirators may be used with a face shield.

- Respirators and masks should be used resourcefully with special consideration for HCF needs.

- In the general population: Surgical masks are most likely ineffective and may even pose an additional risk of infection.

\subsection{Intensive care}

- Indications: Admit to ICU and initiate intubation if any of the following are present:

○ Signs of respiratory failure

○ Dyspnea with hypoxemia

○ Tachypnea $(\mathrm{RR}>30 / \mathrm{min})$

- Airway management: Considering health-care workers have an increased risk of developing COVID19 , especially during high-risk procedures such as intubation, aerosol-generating procedures should be avoided whenever possible $62-64$.

- Endotracheal intubation: Rapid-sequence induction is preferred, especially as it minimizes the spreading of infectious aerosols.

- To avoid aerosolizing the virus, noninvasive ventilation, high-flow oxygen therapy, bronchoscopy, and nebulizer treatment should be avoided unless there is an absolute indication.

- If NIPPV is indicated (e.g., COPD, asthma, DNI status): attempt with a helmet (vs. face mask) interface

- Mechanical breathing: ventilation with lower tidal volumes (LTV) as with ARDS65

○ Moderate tidal volume $(6 \mathrm{~mL} / \mathrm{kg})$

○ Plateau pressure $<30 \mathrm{~cm} \mathrm{H}_{2} \mathrm{O}$

○ Permissive hypercapnia (target $\mathrm{pH}>7.3$ )

$\bigcirc \quad$ PEEP and $\mathrm{FiO}_{2}$ settings: adjust as needed according to ARDSnet protocol 66

- See therapy of ARDS for more information.

\subsection{Medical therapy and Treatment}

Early on, these patients are usually treated with conventional medications which had no clinical benefit, resulting in spread to health care personnel. For those with flu-like symptoms or even more severe disease, it would not be immediately evident that this is an atypical and virulent form of a coronavirus. For comparison, influenza has an estimated mortality rate of $0.07 \%-0.2 \%$. A high index of suspicion is helpful but not foolproof.

The general strategies include bed rest and supportive treatment, including antiviral therapy ${ }^{67}$, antibioics application, immunomodulating therapy68, organ function support, respiratory support, bronchoalveolar lavage (BAL), blood purification and extracorporeal membrane oxygenation (ECMO) ${ }^{69}$.

Potential target structures and agents: A variety of agents are being tested, and clinical studies are being conducted ${ }^{70,71}$.

○ Inhibition of adhesion and invasion

- Camostat (protease inhibitor)

○ Inhibition of fusion

- Chloroquine or less toxic hydroxychloroquine ${ }^{72-75}$

- Hydroxychloroquine In combination with azithromycin is being intensely tested 76

- Umifenovir77

Inhibition of protease

- Lopinavir/ritonavir78-80

- Darunavir/ritonavir (possibly in combination with umifenovir)

- Remdesivir 81,82

○ RNA polymerase inhibitors and nucleotide analogs

- Favipiravir 83 (brand name: Avigan ${ }^{\circledR}$; approved in Japan)

- $\quad$ Remdesivir 81,82

- Baloxavir marboxil

○ Antibody therapy and biologicals 84

- Tocilizumab, especially in the phase of ARDS when IL-6 and CRP are increased 85

- Recombinant ACE2 (rhACE2, APN01) 86

○ Passive immunization through serum therapy: 87

- Immunized individuals (already had COVID-19) donate serum

- Especially a potential option for risk groups

\subsubsection{Antiviral therapy}

To date, there is no anti-viral therapeutics that specifically targets human coronaviruses, so treatment is only supportive. In vitro, interferons (IFNs) are only partially effective against coronaviruses. In vivo, the effectiveness of IFNs combined with ribavirin requires further evaluation. A variety of other agents, including antiviral peptides and corticosteroids have been shown to be effective in vitro and/or in animal models. However, clinical evidence does not support the use of corticosteroid treatment for SARSCoV-2 lung injury.

Antiviral agents and immunomodulators tested against SARS-CoV in animals and in vitro shown in Table $3^{88}$ 
Table 3. Antiviral agent(s) and/or immunomodulator(s) Used in Treatment of Covid- 19

\begin{tabular}{|c|c|c|}
\hline $\begin{array}{l}\text { Antiviral agent(s) and/or } \\
\text { immunomodulator(s) }\end{array}$ & $\begin{array}{l}\text { Study setting and } \\
\text { methods (virus strain) }\end{array}$ & Main findings $^{a}$ \\
\hline IFN- $\alpha B / D$ (hybrid IFN) & BALB/c mice (Urbani) & $\begin{array}{l}\text { i.p. IFN- } \alpha \text { B/D once daily for } 3 \text { days beginning } 4 \text { h after virus } \\
\text { exposure reduced SARS-CoV replication in lungs by } 1 \log _{10} \text { at } \\
10,000 \text { and } 32,000 \mathrm{IU} \text {; at the highest dose of } 100,000 \mathrm{IU} \text {, virus lung } \\
\text { titers were not detectable }\end{array}$ \\
\hline $\begin{array}{l}\text { Ampligen [poly(I:C124)] } \\
\text { (mismatched double- } \\
\text { stranded RNA IFN inducer) }\end{array}$ & BALB/c mice (Urbani) & $\begin{array}{l}\text { i.p. Ampligen at } 10 \mathrm{mg} / \mathrm{kg} 4 \mathrm{~h} \text { after virus exposure reduced virus } \\
\text { lung titers to undetectable levels }\end{array}$ \\
\hline $\begin{array}{l}\text { Pegylated IFN- } \alpha \text { as } \\
\text { prophylactic treatment }\end{array}$ & $\begin{array}{l}\text { Cynomolgus macaques } \\
\text { (Macaca fascicularis) } \\
\text { (patient 5668) }\end{array}$ & $\begin{array}{l}\text { Significantly reduced viral replication and excretion, viral antigen } \\
\text { expression by type } 1 \text { pneumocytes, and pulmonary damage; } \\
\text { postexposure treatment with pegylated IFN- } \alpha \text { yielded } \\
\text { intermediate results }\end{array}$ \\
\hline \multirow[t]{2}{*}{ IFN- $\alpha 2 b$ (Intron A) } & $\begin{array}{l}\text { Vero (FFM-1, HK } \\
\text { isolate) }\end{array}$ & $\begin{array}{l}\text { Mean (SD) } \mathrm{EC}_{50}=4,950(890) \mathrm{IU} / \mathrm{ml}(\mathrm{SI} \text { of }>2) \text { for } \mathrm{FFM}-1 \text { isolate; } \\
\text { mean (SD) } \mathrm{EC}_{50}=6,500(980) \mathrm{IU} / \mathrm{ml}(\mathrm{SI} \text { of }>105) \text { for HK isolate }\end{array}$ \\
\hline & $\begin{array}{l}\text { Caco2 (FFM-1, HK } \\
\text { isolate) }\end{array}$ & $\begin{array}{l}\text { Mean (SD) } \mathrm{EC}_{50}=1,530(220) \mathrm{IU} / \mathrm{ml}(\mathrm{SI} \text { of }>6.5) \text { for } \mathrm{FFM}-1 \text { isolate; } \\
\text { mean (SD) } \mathrm{EC}_{50}=880(130) \mathrm{IU} / \mathrm{ml}(\mathrm{SI} \text { of }>11.4) \text { for } \mathrm{HK} \text { isolate }\end{array}$ \\
\hline \multirow[t]{2}{*}{ 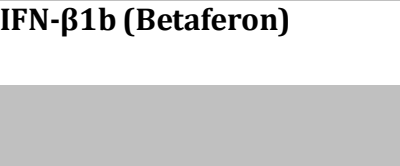 } & $\begin{array}{l}\text { Vero (FFM-1, HK } \\
\text { isolate) }\end{array}$ & $\begin{array}{l}\text { Mean (SD) } \mathrm{EC}_{50}=95(17) \mathrm{IU} / \mathrm{ml}(\mathrm{SI} \text { of }>105) \text { for } \mathrm{FFM}-1 \text { isolate; } \\
\text { mean (SD) } \mathrm{EC}_{50}=105(21) \mathrm{IU} / \mathrm{ml}(\mathrm{SI} \text { of }>95) \text { for HK isolate }\end{array}$ \\
\hline & $\begin{array}{l}\text { Caco2 (FFM-1, HK } \\
\text { isolate) }\end{array}$ & $\begin{array}{l}\text { Mean (SD) } \mathrm{EC}_{50}=21(3.9) \mathrm{IU} / \mathrm{ml}(\mathrm{SI} \text { of }>476) \text { for } \mathrm{FFM}-1 \text { isolate; } \\
\text { mean (SD) } \mathrm{EC}_{50}=9.2(2.1) \mathrm{IU} / \mathrm{ml}(\mathrm{SI} \text { of }>1,087) \text { for HK isolate }\end{array}$ \\
\hline \multirow[t]{2}{*}{ IFN- $\gamma 1 \mathbf{b}$ (Imukin) } & $\begin{array}{l}\text { Vero (FFM-1, HK } \\
\text { isolate) }\end{array}$ & $\begin{array}{l}\text { Mean (SD) } \mathrm{EC}_{50}=2,500(340) \mathrm{IU} / \mathrm{ml}(\mathrm{SI} \text { of }>4) \text { for } \mathrm{FFM}-1 \text { isolate; } \\
\text { mean (SD) } \mathrm{EC}_{50}=1,700(290) \mathrm{IU} / \mathrm{ml}(\mathrm{SI} \text { of }>5.9) \text { for HK isolate }\end{array}$ \\
\hline & $\begin{array}{l}\text { Caco2 (FFM-1, HK } \\
\text { isolate) }\end{array}$ & $\begin{array}{l}\text { Mean (SD) } \mathrm{EC}_{50}=>10,000 \mathrm{IU} / \mathrm{ml}(\mathrm{SI} N \mathrm{NA} \text { ) for FFM-1 isolate; mean } \\
(\mathrm{SD}) \mathrm{EC}_{50}=>10,000 \mathrm{IU} / \mathrm{ml}(\mathrm{SI} \mathrm{NA}) \text { for HK isolate }\end{array}$ \\
\hline 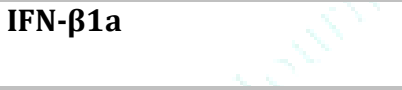 & $\begin{array}{l}\text { Vero E6 (Tor2, Tor7, } \\
\text { and Urbani) }\end{array}$ & $\begin{array}{l}\text { IFN with p.i. } \mathrm{IC}_{50}=50 \mathrm{IU} / \mathrm{ml} \text {; IFN added postinfection } \mathrm{IC}_{50}=500 \\
\mathrm{IU} / \mathrm{ml}\end{array}$ \\
\hline IFN- $\beta$, IFN- $\alpha$, IFN- $\gamma$ & $\begin{array}{l}\text { Vero, MxA-expressing } \\
\text { Vero (FFM-1) }\end{array}$ & $\begin{array}{l}\text { SARS-CoV strongly inhibited by IFN- } \beta \text { (with p.i.) and less so with } \\
\text { IFN- } \alpha \text { and IFN- } \gamma \text {; MxA does not interfere with viral replication }\end{array}$ \\
\hline IFN- $\alpha$, IFN- $\beta$ & FRhK-4 (NMf) & $\begin{array}{l}\downarrow \text { intracellular viral RNA copies; IFN- } \alpha \text { IC }_{50}=25 \mathrm{U} / \mathrm{ml} \text {; IFN- } \beta \text { IC } \mathrm{C}_{50}= \\
14 \mathrm{U} / \mathrm{ml}\end{array}$ \\
\hline IFN- $\alpha 2 b$ & $\begin{array}{l}\text { Vero E6 (Tor2, Tor3, } \\
\text { Tor7, and Tor684) }\end{array}$ & $\mathrm{IC}_{50}=\sim 500 \mathrm{IU} / \mathrm{ml}$ \\
\hline \multirow[t]{2}{*}{ Leu-IFN- $\alpha$} & FRhK-4 (HKU39849) & $\mathrm{EC}_{50}$ at $48 \mathrm{~h}=5,000 \mu \mathrm{g} / \mathrm{ml}$ \\
\hline & Vero E6 (HKU39849) & $\mathrm{EC}_{50}$ at $48 \mathrm{~h}=19.5 \mu \mathrm{g} / \mathrm{ml}$ \\
\hline \multirow[t]{2}{*}{$\begin{array}{l}\text { IFN- } \alpha \text { (p.i. for } 16 \mathrm{~h} \text { before } \\
\text { viral inoculation) }\end{array}$} & FRhK-4 (HKU39849) & $\mathrm{EC}_{50}$ at $48 \mathrm{~h}=39 \mu \mathrm{g} / \mathrm{ml}$ \\
\hline & Vero E6 (HKU39849) & $\mathrm{EC}_{50}$ at $48 \mathrm{~h}=19.5 \mu \mathrm{g} / \mathrm{ml}$ \\
\hline \multirow[t]{2}{*}{ IFN- $\beta$} & FRhK-4 (HKU39849) & $\mathrm{EC}_{50}$ at $48 \mathrm{~h}=200 \mu \mathrm{g} / \mathrm{ml}$ \\
\hline & Vero E6 (HKU39849) & $\mathrm{EC}_{50}$ at $48 \mathrm{~h}=106 \mu \mathrm{g} / \mathrm{ml}$ \\
\hline \multirow[t]{2}{*}{$\begin{array}{l}\text { IFN- } \beta \text { (p.i. for } 16 \mathrm{~h} \text { before } \\
\text { viral inoculation) }\end{array}$} & FRhK-4 (HKU39849) & $\mathrm{EC}_{50}$ at $48 \mathrm{~h}=625 \mu \mathrm{g} / \mathrm{ml}$ \\
\hline & Vero E6 (HKU39849) & $\mathrm{EC}_{50}$ at $48 \mathrm{~h}=19.5 \mu \mathrm{g} / \mathrm{ml}$ \\
\hline 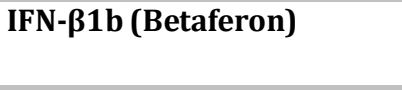 & $\begin{array}{l}\text { Vero E6 } \\
(2003 V A 2774)\end{array}$ & $\mathrm{IC}_{50}=0.2 \mathrm{IU} / \mathrm{ml} ; \mathrm{IC}_{95}=8 \mathrm{IU} \mathrm{ml}$ \\
\hline IFN- $\alpha$ n3 (Alferon) & $\begin{array}{l}\text { Vero E6 } \\
(2003 \text { VA2774) }\end{array}$ & $\mathrm{IC}_{50}=0.8 \mathrm{IU} / \mathrm{ml} ; \mathrm{IC} 95=200 \mathrm{IU} / \mathrm{ml}$ \\
\hline $\begin{array}{l}\text { Human leukocyte IFN- } \alpha \\
\text { (Multiferon) }\end{array}$ & $\begin{array}{l}\text { Vero E6 } \\
(2003 \text { VA2774) }\end{array}$ & $\mathrm{IC}_{50}=2 \mathrm{IU} / \mathrm{ml} ; \mathrm{IC}_{95}=44 \mathrm{IU} / \mathrm{ml}$ \\
\hline IFN- $\beta$ & Vero E6 (FFM-1) & $\mathrm{IC}_{50}=110 \mathrm{IU} / \mathrm{ml}$ at $10 \mathrm{TCID}{ }_{50} ; \mathrm{IC}_{50}=625 \mathrm{IU} / \mathrm{ml}$ at $100 \mathrm{TCID}_{50}$ \\
\hline Multiferon & Vero E6 (FFM-1) & $\mathrm{IC}_{50}=540 \mathrm{IU} / \mathrm{ml}$ at $10 \mathrm{TCID} 50 ; \mathrm{IC}_{50}=2,400 \mathrm{IU} / \mathrm{ml}$ at $100 \mathrm{TCID}_{50}$ \\
\hline IFN- $\alpha 2 b$ & Vero E6 (FFM-1) & $\begin{array}{l}\mathrm{IC}_{50}=>3,125 \mathrm{IU} / \mathrm{ml} \text { at } 10 \mathrm{TCID}_{50} ; \mathrm{IC}_{50}=>3,125 \mathrm{IU} / \mathrm{ml} \text { at } 100 \\
\mathrm{TCID}_{50}\end{array}$ \\
\hline IFN- $\alpha 2 \mathbf{a}$ & Vero E6 (FFM-1) & $\begin{array}{l}\mathrm{IC}_{50}=>3,125 \mathrm{IU} / \mathrm{ml} \text { at } 10 \mathrm{TCID}_{50} ; \mathrm{IC}_{50}=>3,125 \mathrm{IU} / \mathrm{ml} \text { at } 100 \\
\mathrm{TCID}_{50}\end{array}$ \\
\hline IFN-alfacon1 (Infergen) & Vero (Urbani) & $\mathrm{IC}_{50}=0.001 \mu \mathrm{g} / \mathrm{ml}$ \\
\hline IL-4 and IFN- $\gamma$ & Vero E6 (HKU39849) & $\begin{array}{l}\text { IL- } 4 \text { and IFN- } \gamma \text { downregulated cell surface expression of ACE2; } \\
\text { ACE2 mRNA levels were also decreased after treatment }\end{array}$ \\
\hline IFN- $\beta$ and ribavirin & Caco2 (FFM-1) & Mean (SD) CI = $0.45(0.07)$ \\
\hline
\end{tabular}




\begin{tabular}{|c|c|c|}
\hline $\begin{array}{l}\text { HR2-8 (HR2-derived } \\
\text { peptide) }\end{array}$ & Vero $118(\mathrm{NM})$ & $\mathrm{EC}_{50}=17 \mu \mathrm{M}$ \\
\hline CP-1 (HR2-derived peptide) & Vero E6 (WHU) & $\mathrm{IC}_{50} \approx 19 \mu \mathrm{mol} / \mathrm{liter}$ \\
\hline $\begin{array}{l}\text { HR1-1 (HR1-derived } \\
\text { peptide) }\end{array}$ & $\begin{array}{l}\text { Vero E6 (BJ01 and } \\
\text { pseudovirus) }\end{array}$ & $\begin{array}{l}\mathrm{EC}_{50}=3.68 \mu \mathrm{M} \text { for wild-type virus assay; } \mathrm{EC}_{50}=0.14 \mu \mathrm{M} \text { for } \\
\text { pseudotyped virus assay }\end{array}$ \\
\hline $\begin{array}{l}\text { HR2-18 (HR2-derived } \\
\text { peptide) }\end{array}$ & $\begin{array}{l}\text { Vero E6 (BJ01 and } \\
\text { pseudovirus) }\end{array}$ & $\begin{array}{l}\mathrm{EC}_{50}=5.22 \mu \mathrm{M} \text { for wild-type virus assay; } \mathrm{EC}_{50}=1.19 \mu \mathrm{M} \text { for } \\
\text { pseudotyped virus assay }\end{array}$ \\
\hline HR2 & Vero E6 (WHU) & $\begin{array}{l}\text { CPE inhibition IC } 50=0.5-5 \mathrm{nM} \text { (synthetic HR2 peptide) and 66.2- } \\
500 \mathrm{nM} \text { (fusion HR2 peptide) }\end{array}$ \\
\hline $\begin{array}{l}\text { Peptides representing } \\
\text { various regions of ACE } 2\end{array}$ & $\begin{array}{l}\text { TELCeB6, HeLa, and } \\
\text { VeroE6 (pseudovirus) }\end{array}$ & $\begin{array}{l}\mathrm{IC}_{50}=50 \mu \mathrm{M} \text { (peptide aa 22-44); } \mathrm{IC}_{50}=6 \mu \mathrm{M} \text { (peptide aa 22-57); } \\
\mathrm{IC}_{50}=0.1 \mu \mathrm{M} \text { (peptide aa 22-44 and 351-357) artificially linked by } \\
\text { glycine }\end{array}$ \\
\hline $\begin{array}{l}\text { Peptides analogous to viral } \\
\text { spike protein }\end{array}$ & Vero E6, L2 (Urbani) & $\begin{array}{l}\text { Inhibit viral plaque formation by } 40-70 \% \text { at } 15-30 \mu \mathrm{M} \text {; peptides } \\
\text { analogous to regions of the } \mathrm{N} \text { terminus or the pretransmembrane } \\
\text { domain of the S2 subunit; inhibit viral plaque formation by }>80 \% \\
\text { at } 15-30 \mu \mathrm{M} \text { (peptides analogous to the SARS-CoV loop region) }\end{array}$ \\
\hline siRNA, RL004, RL005 & Vero E6 (Y3) & $\begin{array}{l}\text { siRNA ( } 600 \mathrm{pmol} / \text { liter) targeting conserved regions of SARS-CoV, } \downarrow \\
\text { virally induced CPE at } 67 \mathrm{~h}\end{array}$ \\
\hline SiRNA & FRhK-4 (HKU66078) & $\begin{array}{l}\text { siRNA duplexes targeting regions in entire viral genome, } \downarrow \text { virally } \\
\text { induced CPE and viral production at } 72 \mathrm{~h}\end{array}$ \\
\hline siRNA targeting viral RP & Vero (NM) & $\begin{array}{l}\downarrow \text { virally induced CPE, } \downarrow \text { viral production, } \downarrow \text { viral protein synthesis } \\
\text { at } 1.5 \text { or } 3 \mu \text { g of siRNA }\end{array}$ \\
\hline $\begin{array}{l}\text { RNA interference targeting } \\
\text { viral RP }\end{array}$ & $\begin{array}{l}\text { Vero E6, 293, HeLa } \\
\text { (SARS-CoV-p9) }\end{array}$ & $\begin{array}{l}\downarrow \text { expression of RP ( } 293 \text { and HeLa cells); } \downarrow \text { plaque formation at } 1 \mu \mathrm{g} \\
\text { of siRNA }\end{array}$ \\
\hline siRNA targeting $S$ gene & Vero E6, 293T (BJ01) & $\begin{array}{l}\downarrow \text { S gene expression in SARS-CoV-infected cells at } 2,3 \text {, and } 4 \mu \mathrm{g} \text { of } \\
\text { siRNA }\end{array}$ \\
\hline $\begin{array}{l}\text { siRNAs targeting } S \text { gene and } \\
3^{\prime} \text { untranslated region }\end{array}$ & Vero E6 (HK strain) & $\begin{array}{l}\downarrow \text { viral antigen synthesis of } 64 \% \text { (by siSARS-S2), } 51 \% \text { (siSARS-S3), } \\
40 \% \text { (siSARS 3' untranslated region) at } 100 \text { pmol of siRNA }\end{array}$ \\
\hline \multirow[t]{3}{*}{ Glycyrrhizin } & Vero (FFM-1, FFM-2) & $\begin{array}{l}\mathrm{CPE} \text { assay mean (SD) } \mathrm{CC}_{50}=>20,000 \mathrm{mg} / \mathrm{liter} ; \mathrm{EC}_{50}=300(51) \\
\mathrm{mg} / \text { liter }(\mathrm{SI} \text { of }>67 \text { ) }\end{array}$ \\
\hline & FRhK-4 (HKU39849) & $\mathrm{EC}_{50}$ at $48 \mathrm{~h}=>400 \mu \mathrm{g} / \mathrm{ml}$ \\
\hline & Vero E6 (HKU39849) & $\mathrm{EC}_{50}$ at $48 \mathrm{~h}=100 \mu \mathrm{g} / \mathrm{ml}$ \\
\hline \multirow[t]{2}{*}{ Mizoribine } & Vero E6 (FFM-1) & $\mathrm{IC}_{50}=3.5 \mu \mathrm{g} / \mathrm{ml} ; \mathrm{CC}_{50}=>200 \mu \mathrm{g} / \mathrm{ml}$ \\
\hline & Vero E6 (HKU39489) & $\mathrm{IC}_{50}=16 \mu \mathrm{g} / \mathrm{ml}$ \\
\hline \multirow[t]{4}{*}{ Ribavirin } & Vero E6 (FFM-1) & $\mathrm{IC}_{50}=20 \mu \mathrm{g} / \mathrm{ml} ; \mathrm{CC}_{50}=>200 \mu \mathrm{g} / \mathrm{ml}$ \\
\hline & Vero E6 (HKU39489) & $\mathrm{IC}_{50}=80 \mu \mathrm{g} / \mathrm{ml}$ \\
\hline & FRhK-4 (HKU39849) & $\mathrm{EC}_{50}$ at $48 \mathrm{~h}=50-100 \mu \mathrm{g} / \mathrm{ml}$ \\
\hline & Vero E6 (HKU39849) & $\mathrm{EC}_{50}$ at $48 \mathrm{~h}=>200 \mu \mathrm{g} / \mathrm{ml}$ \\
\hline \multirow[t]{2}{*}{ Rimantidine } & FRhK-4 (HKU39849) & $\mathrm{EC}_{50}$ at $48 \mathrm{~h}=16 \mu \mathrm{g} / \mathrm{ml}$ \\
\hline & Vero E6 (HKU39849) & $\mathrm{EC}_{50}$ at $48 \mathrm{~h}=8-16 \mu \mathrm{g} / \mathrm{ml}$ \\
\hline \multirow[t]{2}{*}{ Lopinavir } & FRhK-4 (HKU39849) & $\mathrm{EC}_{50}$ at $48 \mathrm{~h}=16 \mu \mathrm{g} / \mathrm{ml}$ \\
\hline & Vero E6 (HKU39849) & $\mathrm{EC}_{50}$ at $48 \mathrm{~h}=8-16 \mu \mathrm{g} / \mathrm{ml}$ \\
\hline \multirow[t]{2}{*}{ Baicalin } & FRhK-4 (HKU39849) & $\mathrm{EC}_{50}$ at $48 \mathrm{~h}=12.5 \mu \mathrm{g} / \mathrm{ml}$ \\
\hline & Vero E6 (HKU39849) & $\mathrm{EC}_{50}$ at $48 \mathrm{~h}=100 \mu \mathrm{g} / \mathrm{ml}$ \\
\hline Aurintricarboxylic acid & Vero (NM) & $\mathrm{EC}_{50}=0.2 \mathrm{mg} / \mathrm{ml} ; \mathrm{CC}_{50}=37.5 \mathrm{mg} / \mathrm{ml} ; \mathrm{SI}=187$ \\
\hline Reserpine & Vero E6 (HK strain) & $\mathrm{EC}_{50}=3.4 \mu \mathrm{M} ; \mathrm{CC}_{50}=25 \mu \mathrm{M} ; \mathrm{SI}=7.3$ \\
\hline Aescin & Vero E6 (HK strain) & $\mathrm{EC}_{50}=6 \mu \mathrm{M} ; \mathrm{CC}_{50}=15 \mu \mathrm{M} ; \mathrm{SI}=2.5$ \\
\hline Valinomycin & Vero E6 (HK strain) & $\mathrm{EC}_{50}=0.85 \mu \mathrm{M} ; \mathrm{CC}_{50}=68 \mu \mathrm{M} ; \mathrm{SI}=80$ \\
\hline Niclosamide & $\begin{array}{l}\text { Vero E6 (Taiwan } \\
\text { strain) }\end{array}$ & $\mathrm{EC}_{50}=1-3 \mu \mathrm{M} ; \mathrm{CC}_{50}=250 \mu \mathrm{M}$ \\
\hline Nelfinavir & Vero E6 (FFM-1) & $\begin{array}{l}\text { Mean (SD) } \mathrm{EC}_{50}=0.048(0.024) \mu \mathrm{M} ; \mathrm{CC}_{50}=14.75(2.75) \mu \mathrm{M} ; \mathrm{SI}= \\
302.1\end{array}$ \\
\hline \multirow[t]{2}{*}{ Chloroquine } & Vero E6 (FFM-1) & Mean (SD) IC $\mathrm{C}_{50}=8.8(1.2) \mu \mathrm{M} ; \mathrm{CC}_{50}=261.3(14.5) \mu \mathrm{M} ; \mathrm{SI}=30$ \\
\hline & Vero E6 (Urbani) & $\begin{array}{l}\text { Mean }(\mathrm{SD}) \mathrm{EC}_{50}=4.4(1.0) \mu \mathrm{M} \text {; refractory to infection if pretreated } \\
\text { with chloroquine }(10 \mu \mathrm{M}) \text { for } 20 \mathrm{~h}\end{array}$ \\
\hline Indomethacin & Vero E6 (Tor2) & $\mathrm{IC}_{50}=50 \mu \mathrm{M}$ \\
\hline \multicolumn{3}{|l|}{ 3C-like proteinase inhibitors } \\
\hline Cinanserin (SQ 10,643) & Vero (NM) & $\mathrm{IC}_{50}=5 \mu \mathrm{M}$ \\
\hline TG-0205221 & Vero E6 (NM) & $\downarrow$ viral load by 4.7 logs at $5 \mu \mathrm{M}$ \\
\hline Octapeptide AVLQSGFR & Vero (BJ01) & $\mathrm{EC}_{50}=0.027 \mathrm{mg} / \mathrm{liter} ; \mathrm{CC}_{50}=>100 \mathrm{mg} /$ liter; $\mathrm{SI}=>3,704$ \\
\hline
\end{tabular}




\begin{tabular}{|c|c|c|}
\hline Peptidomimetic inhibitor & NM & $\mathrm{IC}_{50}=45-70 \mu \mathrm{M}$ \\
\hline $\begin{array}{l}\text { Calpain inhibitors, Val-Leu- } \\
\text { CHO }\end{array}$ & Vero E6 (Urbani) & $\mathrm{EC}_{90}=3 \mu \mathrm{M}$ \\
\hline $\begin{array}{l}\text { Calpain inhibitors, Z-Val- } \\
\text { Phe-Ala-CHO }\end{array}$ & Vero E6 (Urbani) & $\mathrm{EC}_{90}=15 \mu \mathrm{M}$ \\
\hline $\begin{array}{l}\text { Cyclopentenyl carbocyclic } \\
\text { nucleosides }\end{array}$ & NM & $\begin{array}{l}\mathrm{EC}_{50}=47 \mu \mathrm{M} \text { for } 1,2,3 \text {-triazole analogue }(17 \mathrm{c}) ; \mathrm{EC}_{50}=21 \mu \mathrm{M} \text { for } \\
1,2,4 \text {-triazole analogue }(17 \mathrm{a})\end{array}$ \\
\hline $\begin{array}{l}\text { Nucleoside analogue } \\
\text { inhibitor, } \beta \text {-d- } N^{4-} \\
\text { hydroxycytidine }\end{array}$ & Vero E6 (Urbani) & $\mathrm{EC} 90=6 \mu \mathrm{M}$ \\
\hline $\begin{array}{l}\text { Nitric oxide, } S \text {-nitroso- } N \text { - } \\
\text { acetylpenicillamine }\end{array}$ & Vero E6 (FFM-1) & Mean (SD) IC $\mathrm{C}_{50}=222(83.7) \mu \mathrm{M} ; \mathrm{SI}=3$ \\
\hline Pyridine $N$-oxide derivatives & $\begin{array}{l}\text { Crandel feline kidney } \\
\text { (CRFK) and Vero } \\
\text { (FFM-1) }\end{array}$ & $\begin{array}{l}\text { Among } 192 \text { compounds tested, the oxide part on pyridine moiety } \\
\text { was indispensable for antiviral activity with } \text { CC }_{50} \text { of } 50-100 \\
\mathrm{mg} / \text { liter }\end{array}$ \\
\hline Stilbene derivatives & Vero E6 (NM) & $\begin{array}{l}\text { Inhibited by compounds } 17 \text { and } 19 \text { at } 0.5 \mathrm{mg} / \mathrm{ml} \text {, and no significant } \\
\text { cytotoxic effects were observed in vitro }\end{array}$ \\
\hline $\begin{array}{l}\text { Peptide-conjugated } \\
\text { antisense morpholino } \\
\text { oligomers (P-PMO) }\end{array}$ & Vero E6 (Tor2) & $\begin{array}{l}\text { Several virus-targeted P-PMO (AUG1, AUG2, AUG3, 1AFBS, and } \\
\text { 3UTR) consistently reduced CPE at a concn of } 20 \mu \mathrm{M}\end{array}$ \\
\hline $\begin{array}{l}\text { 20-mer synthetic peptides (S } \\
\text { protein fragments) }\end{array}$ & FRhK-4 (GZ50) & $\mathrm{IC}_{50}=24.9-113 \mu \mathrm{g} / \mathrm{ml} ; \mathrm{IC}_{90}=0.9-15.9 \mu \mathrm{g} / \mathrm{ml}$ \\
\hline $\begin{array}{l}\text { Diverse small molecules, }{ }^{b} \\
\text { MP576, HE602, and VE607 }\end{array}$ & Vero (HKU39849) & $\mathrm{EC}_{50}=<10 \mu \mathrm{M}$ \\
\hline $\begin{array}{l}\text { Adamantane-derived } \\
\text { compounds } c\end{array}$ & FRhK-4 (NM) & $\mathrm{IC}_{50}=0.5-3 \mu \mathrm{M} ; \mathrm{CC}_{50}=>300 \mu \mathrm{M}$ \\
\hline \multicolumn{3}{|l|}{$\begin{array}{l}\text { Semisynthetic derivatives of } \\
\text { glycopeptide }\end{array}$} \\
\hline Vancomycin & Vero E6 (FFM-1) & $\mathrm{EC}_{50}=22->100 \mu \mathrm{M} ; \mathrm{CC}_{50}=>80 \mu \mathrm{M}$ \\
\hline Eremomycin & Vero E6 (FFM-1) & $\mathrm{EC}_{50}=14->100 \mu \mathrm{M} ; \mathrm{CC}_{50}=45->100 \mu \mathrm{M}$ \\
\hline $\begin{array}{l}\text { Teicoplanin, ristocetin A, } \\
\text { and DA-40926 }\end{array}$ & Vero E6 (FFM-1) & $\mathrm{EC}_{50}=>80 \mu \mathrm{M} ; \mathrm{CC}_{50}=>80 \mu \mathrm{M}$ \\
\hline $\begin{array}{l}\text { Lycoris radiata (Chinese } \\
\text { medicinal herb) }\end{array}$ & Vero E6 (BJ001, BJ006) & Mean (SD) $\mathrm{EC}_{50}=2.4(0.2) \mu \mathrm{g} / \mathrm{ml} ; \mathrm{CC}_{50}=886.6(35.0) \mu \mathrm{g} / \mathrm{ml}$ \\
\hline $\begin{array}{l}\text { Artemisia annua (Chinese } \\
\text { medicinal herb) }\end{array}$ & Vero E6 (BJ001, BJ006) & Mean (SD) $\mathrm{EC}_{50}=34.5(2.6) \mu \mathrm{g} / \mathrm{ml} ; \mathrm{CC}_{50}=1,035(92.8) \mu \mathrm{g} / \mathrm{ml}$ \\
\hline $\begin{array}{l}\text { Pyrrosia lingua (Chinese } \\
\text { medicinal herb) }\end{array}$ & Vero E6 (BJ001, BJ006) & Mean (SD) EC $50=43.2(14.1) \mu \mathrm{g} / \mathrm{ml} ; \mathrm{CC}_{50}=2,378(87.3) \mu \mathrm{g} / \mathrm{ml}$ \\
\hline $\begin{array}{l}\text { Lindera sp. (Chinese } \\
\text { medicinal herb) }\end{array}$ & Vero E6 (BJ001, BJ006) & Mean (SD) EC $50=88.2(7.7) \mu \mathrm{g} / \mathrm{ml} ; \mathrm{CC}_{50}=1,374(39.0) \mu \mathrm{g} / \mathrm{ml}$ \\
\hline
\end{tabular}

- $\quad a$ i.p., intraperitoneal; $\mathrm{EC}_{50}, 50 \%$ effective concentration; SI, selectivity index; NA, not available; p.i., preincubation; NM, not mentioned; $\mathrm{IC}_{50}, 50 \%$ inhibitory concentration; $\mathrm{TCID}_{50}, 50 \%$ tissue culture infective dose; $\mathrm{CI}$, combination index (combination index of $<1$ indicates synergism); CPE, cell culture cytopathic effect; aa, amino acids; RP, RNA polymerase; $\mathrm{CC}_{50}, 50 \%$ cytotoxic concentration; $\downarrow$, decreased.

- $\quad b$ MP576, HE602, and VE607 were validated to be inhibitors of SARS-CoV Mpro, Hel, and viral entry, respectively.

- $\quad c$ Bananin, iodobananin, vanillinbananin, and eubananin were effective inhibitors of the ATPase activity of the SCV helicase.

\subsubsection{Immuno enhancement therapy}

Synthetic recombinant interferon $\alpha$ has proven to be effective in treatment of SARS patients in clinic trials 89 . Pulmonary Xray abnormal remission time was reduced by $50 \%$ in the interferon-treated group compared with the glucocorticoidtreated group alone. Interferon was also found to be an effective inhibitor of MERS-CoV replication ${ }^{90}$. Those findings suggested that interferon could be used in the treatment of COVID-19. Intravenous immunoglobulin might be the safest immunomodulator for long-term use in all ages, and could help to inhibit the production of proinflammatory cytokines and increase the production of anti-inflammatory mediators ${ }^{91}$ Moreover, Thymosin alpha-1 (Ta1) can be an immune booster for SARS patients, effectively controlling the spread of disease $^{92}$. Intravenous immunoglobulin and Ta1 may also be considered as therapeutics for COVID-19.

A retrospective review analyzed 21 patients in which tocilizumab was added to standard COVID-19 therapy.(25) Preliminary data suggest tocilizumab may have clinical benefit as adjunctive therapy. Tocilizumab is Interleukin-6 (IL-6) Receptor-Inhibiting Monoclonal Antibody

that can cause Cytokine release syndrome may be a component of severe disease in COVID-19 patients ${ }^{93}$.The Mechanism of Action of said that it inhibits IL-6-mediated signaling by competitively binding to both soluble and membrane-bound IL-6 receptors. IL-6 is a proinflammatory cytokine that is involved in diverse physiological processes such as T-cell activation, immunoglobulin secretion induction, 
hepatic acute-phase protein synthesis initiation, and hematopoietic precursor cell proliferation and differentiation stimulation. IL-6 is produced by various cell types, including Tand B-cells, lymphocytes, monocytes, and fibroblasts.

\subsubsection{Convalescent plasma therapy}

When there are no sufficient vaccines and specific drugs, convalescent plasma therapy could be an effective way to alleviate the course of disease for severely infected patients ${ }^{94}$. Plasma collected from persons who have recovered from COVID-19 that may contain antibodies to SARS-CoV-2 Clinical trials are being conducted to evaluate the use of COVID-19 convalescent plasma to treat patients with severe or immediately life-threatening COVID-19 infections.Moreover, from the perspective of immunology, most of the patients recovered from COVID-19 would produce specific antibodies against the SARS-CoV-2, and their serum could be used to prevent reinfection. At the same time, antibodies can limit the virus reproduction in the acute phase of infection and help clear the virus, which is conducive to the rapid recovery of the disease $^{95}$

Corticosteroids therapy: Corticosteroid therapy is not recommended for viral pneumonia; however, use may be considered for patients with refractory shock or acute respiratory distress syndrome.

\subsubsection{Vaccine Development}

Vaccines that have been developed are either not effective, or in some cases have been reported to be involved in the selection of novel pathogenic CoVs via recombination of circulating strains Vaccine development can be a challenge. It is noteworthy that almost 20 years after SARS, there is still no vaccine for coronavirus. After SARS, development of a vaccine appeared to be the best approach to prevent future SARS-CoV epidemics. However, there were many obstacles in SARS vaccine development. Firstly, researchers did not have a comprehensive understanding of the pathogenic mechanism of SARS-CoV. Secondly, animal models of SARS-CoV infection could not simulate human disease because of an incongruent pathogenesis. Thirdly, in order to test the efficacy, many people must be tested in areas where the virus is endemic. Although several candidate vaccines against SARS-CoV have been produced and tested, at present, unfortunately, there is no FDA approved vaccine against SARS ${ }^{96}$.

\section{Rigorous infection control}

1. Contact tracing, strict isolation of actively ill patients and quarantine of close contacts should be implemented early ${ }^{97}$.

2. Environmental hygiene in medical sectors and personal hygiene of health care workers should be maintained ${ }^{98}$, 99 .

3. Training in the use of personal protective equipment protects the safety of HCWs ${ }^{100}$.

4. Establishing fever clinics, setting up designated hospital wards and SARS hospitals reduced human-to-human transmission 101

5. Education of the public on communicable diseases and what measures to take on a personal basis to prevent spread.

\section{Conclusion and Recommendation}

Looking ahead, the most feasible options that should be further evaluated in clinical trials for the ongoing Covid 19 epidemic. The COVID-19 pandemic is spreading across the globe at an alarming rate. It has caused more infections and deaths as compared with SARS or MERS. The rapid spread of disease warrants intense surveillance and isolation protocols to prevent further transmission. No confirmed medication or vaccine has been developed. Current treatment strategies are aimed at symptomatic care and oxygen therapy. Prophylactic vaccination is required for the future prevention of COVrelated epidemic or pandemic. To reduce the risk of transmission in the community, individuals should be advised or recommended to wash hands diligently, practice respiratory hygiene (eg, cover their cough), and avoid crowds and close contact with ill individuals, if possible. Facemasks are not routinely recommended for asymptomatic individuals to prevent exposure in the community. Social distancing is advised, particularly in locations that have community transmission. The strict control of cross-infection in medical institutions is also key to preventing the further spread of the epidemic.

\section{Acknowledgements}

The authors are thankful to Dr. Surendra Kumar Jain Director SIRTSP for their

\section{References}

1. Perlman S, Netland J. Coronaviruses post-SARS: update on replication and pathogenesis. Nature reviews microbiology. 2009; 7:439-50.

2. Yang D, Leibowitz JL. The structure and functions of coronavirus genomic $3^{\prime}$ and $5^{\prime}$ ends. Virus research. 2015 3; 206:120-33.

3. Drosten C, Günther S, Preiser W, Van Der Werf S, Brodt HR, Becker S, Rabenau H, Panning M, Kolesnikova L, Fouchier RA, Berger A. Identification of a novel coronavirus in patients with severe acute respiratory syndrome. New England journal of medicine. 2003; 348:1967-76.

4. Cotten M, Lam TT, Watson SJ, Palser AL, Petrova V, Grant P, Pybus OG, Rambaut A, Guan Y, Pillay D, Kellam P. Full-genome deep sequencing and phylogenetic analysis of novel human betacoronavirus. Emerging infectious diseases. 2013; 19:736.

5. Zhu N, Zhang D, Wang W, Li X, Yang B, Song J, Zhao X, Huang B, Shi W, Lu R, Niu P. A novel coronavirus from patients with pneumonia in China, 2019. New England Journal of Medicine. 2020:24.

6. Cui J, Li F, Shi ZL. Origin and evolution of pathogenic coronaviruses. Nature reviews Microbiology. 2019; 17:181-92.

7. Maclachlan NJ, Dubovi EJ, editors. Fenner's veterinary virology. Academic press; 2010:26.

8. Su S, Wong G, Shi W, Liu J, Lai AC, Zhou J, Liu W, Bi Y, Gao GF. Epidemiology, genetic recombination, and pathogenesis of coronaviruses. Trends in microbiology. 2016; 24:490-502.

9. Khan S, Siddique R, Shereen MA, Ali A, Liu J, Bai Q, Bashir N, Xue M. The emergence of a novel coronavirus (SARS-CoV-2), their biology and therapeutic options. Journal of clinical microbiology. 2020.

10. Isaacs D, Flowers D, Clarke JR, Valman HB, MacNaughton MR. Epidemiology of coronavirus respiratory infections. Archives of disease in childhood. 1983; 58:500-3.

11. Greenberg SB. Update on human rhinovirus and coronavirus infections. InSeminars in respiratory and critical care medicine 2016;37: 555-571.

12. Zaki AM, Van Boheemen S, Bestebroer TM, Osterhaus AD, Fouchier RA. Isolation of a novel coronavirus from a man with pneumonia in Saudi Arabia. New England Journal of Medicine. 2012; 367:1814-20.

13. Weiss SR, Navas-Martin S. Coronavirus pathogenesis and the emerging pathogen severe acute respiratory syndrome coronavirus. Microbiol. Mol. Biol. Rev. 2005; 69:635-64.

14. Wu A, Peng Y, Huang B, Ding X, Wang X, Niu P, Meng J, Zhu Z, Zhang Z, Wang J, Sheng J. Genome composition and divergence of the novel coronavirus (2019-nCoV) originating in China. Cell host \& microbe. 2020

15. Sabir JS, Lam TT, Ahmed MM, Li L, Shen Y, Abo-Aba SE, Qureshi MI, Abu-Zeid M, Zhang Y, Khiyami MA, Alharbi NS. Co-circulation of three camel coronavirus species and recombination of MERSCoVs in Saudi Arabia. Science. 2016; 35:81-4.

16. Zhao Z, Li H, Wu X, Zhong Y, Zhang K, Zhang YP, Boerwinkle E, Fu YX. Moderate mutation rate in the SARS coronavirus genome and its implications. BMC evolutionary biology. 2004; 4:21. 
17. Woo PC, Lau SK, Yuen KY. Infectious diseases emerging from Chinese wet-markets: zoonotic origins of severe respiratory viral infections. Current opinion in infectious diseases. 2006; 19:401-7.

18. Woo PC, Lau SK, Huang Y, Yuen KY. Coronavirus diversity, phylogeny and interspecies jumping. Experimental Biology and Medicine. 2009; 234:1117-27.

19. Woo PC, Lau SK, Yip CC, Huang Y, Tsoi HW, Chan KH, Yuen KY. Comparative analysis of 22 coronavirus HKU1 genomes reveals a novel genotype and evidence of natural recombination in coronavirus HKU1. Journal of virology. 2006; 80:7136-45.

20. Benvenuto D, Giovanetti M, Ciccozzi A, Spoto S, Angeletti S, Ciccozzi M. The 2019-new coronavirus epidemic: evidence for virus evolution. Journal of Medical Virology. 2020; 92:455-9.

21. Ceraolo C, Giorgi FM. Genomic variance of the 2019-nCoV coronavirus. Journal of Medical Virology. 2020.

22. Lau SK, Li KS, Huang Y, Shek CT, Tse H, Wang M, Choi GK, Xu H, Lam CS, Guo R, Chan KH. Ecoepidemiology and complete genome comparison of different strains of severe acute respiratory syndrome-related Rhinolophus bat coronavirus in China reveal bats as a reservoir for acute, self-limiting infection that allows recombination events. Journal of virology. 2010; 84:2808-19.

23. Li W, Shi Z, Yu M, Ren W, Smith C, Epstein JH, Wang H, Crameri G, $\mathrm{Hu}$ Z, Zhang $\mathrm{H}$, Zhang J: Bats are natural reservoirs of SARS-like coronaviruses. Science 2005; 310:676-9.

24. Lu H, Stratton CW, Tang YW: Outbreak of Pneumonia of Unknown Etiology in Wuhan China: the Mystery and the Miracle. Journal of Medical Virology.

25. Ji W, Wang W, Zhao X, Zai J, Li X. Cross-species transmission of the newly identified coronavirus 2019-nCoV. Journal of medical virology 2020: 433-40.

26. J Chan JF, Yuan S, Kok KH, To KK, Chu H, Yang J, Xing F, Liu J, Yip CC, Poon RW, Tsoi HW. A familial cluster of pneumonia associated with the 2019 novel coronavirus indicating person-to-person transmission: a study of a family cluster. The Lancet. 2020; 395:514-23.

27. Nishiura H, Linton NM, Akhmetzhanov AR. Initial cluster of novel coronavirus (2019-nCoV) infections in Wuhan, China is consistent with substantial human-to-human transmission. J. Clin. Med. 2020; 9:E488

28. Organization, W.H., Consensus Document on the Epidemiology of Severe Acute Respiratory Syndrome (SARS). 2003, World Health Organization: Geneva.

29. Maier HJ, Bickerton E, Britton P. Coronaviruses: methods and protocols. Springer Berlin; 2015: 1-282

30. Malik M, Elkholy AA, Khan W, Hassounah S, Abubakar A, Minh NT, Mala P. Middle East respiratory syndrome coronavirus: current knowledge and future considerations. EMHJ-Eastern Mediterranean Health Journal. 2016; 22:533-42.

31. Lu CW, Liu XF, Jia ZF. 2019-nCoV transmission through the ocular surface must not be ignored. The Lancet. 2020 Feb 22; 395(10224):e39.

32. Chen Y, Liu Q, Guo D. Emerging coronaviruses. genome structure, replication, and pathogenesis. Journal of medical virology. 2020; 92:418-23.

33. Cookson BT, Brennan MA. Pro-inflammatory programmed cell death. Trends in microbiology. 2001; 3:113-4.

34. Chen IY, Moriyama M, Chang MF, Ichinohe T. Severe acute respiratory syndrome coronavirus viroporin 3a activates the NLRP3 inflammasome. Frontiers in microbiology. 2019; 10.

35. Chen IY, Moriyama M, Chang MF, Ichinohe T. Severe acute respiratory syndrome coronavirus viroporin $3 \mathrm{a}$ activates the NLRP3 inflammasome. Frontiers in microbiology. 2019; 10.

36. Yang M. Cell pyroptosis, a potential pathogenic mechanism of 2019-nCoV infection. Available at SSRN 3527420. 2020.

37. Yeo C, Kaushal S, Yeo D. Enteric involvement of coronaviruses: is faecal-oral transmission of SARS-CoV-2 possible?. The Lancet Gastroenterology \& Hepatology. 2020; 5:335-7.

38. Wang D, Hu B, Hu C, Zhu F, Liu X, Zhang J, Wang B, Xiang H, Cheng Z, Xiong Y, Zhao Y. Clinical characteristics of 138 hospitalized patients with 2019 novel coronavirus-infected pneumonia in Wuhan, China. Jama. 2020.

39. Leung GM, Hedley AJ, Ho LM, Chau P, Wong IO, Thach TQ, Ghani AC, Donnelly CA, Fraser C, Riley S, Ferguson NM. The epidemiology of severe acute respiratory syndrome in the 2003 Hong Kong epidemic: an analysis of all 1755 patients. Annals of internal medicine. 2004; 141:662-73.
40. Guan WJ, Ni ZY, Hu Y, Liang WH, Ou CQ, He JX, Liu L, Shan H, Lei CL, Hui DS, Du B. Clinical characteristics of 2019 novel coronavirus infection in China. MedRxiv. 2020.

41. Li Q, Guan X, Wu P, Wang X, Zhou L, Tong Y, Ren R, Leung KS, Lau EH, Wong JY, Xing X. Early transmission dynamics in Wuhan, China, of novel coronavirus-infected pneumonia. New England Journal of Medicine. 2020.

42. Yin Y, Wunderink RG. MERS, SARS and other coronaviruses as causes of pneumonia. Respirology. 2018; 23130-7.

43. Huang C, Wang Y, Li X, Ren L, Zhao J, Hu Y, Zhang L, Fan G, Xu J, Gu X, Cheng Z. Clinical features of patients infected with 2019 novel coronavirus in Wuhan, China. The Lancet. 2020; 395:497-506.

44. Ksiazek TG, Erdman D, Goldsmith CS, Zaki SR, Peret T, Emery S, Tong S, Urbani C, Comer JA, Lim W, Rollin PE. A novel coronavirus associated with severe acute respiratory syndrome. New England journal of medicine. 2003; 348:1953-66.

45. Chen N, Zhou M, Dong X, Qu J, Gong F, Han Y, Qiu Y, Wang J, Liu Y, Wei Y, Yu T. Epidemiological and clinical characteristics of 99 cases of 2019 novel coronavirus pneumonia in Wuhan, China: a descriptive study. The Lancet. 2020; 395:507-13.

46. Qiao J. What are the risks of COVID-19 infection in pregnant women?. The Lancet. 2020; 395:760-2.

47. Yi Y, Lagniton PN, Ye S, Li E, Xu RH. COVID-19: what has been learned and to be learned about the novel coronavirus disease. International Journal of Biological Sciences. 2020; 16:1753.

48. Shen K, Yang Y, Wang T, Zhao D, Jiang Y, Jin R, Zheng Y, Xu B, Xie Z Lin L, Shang Y. Diagnosis, treatment, and prevention of 2019 novel coronavirus infection in children: experts' consensus statement. World Journal of Pediatrics. 2020:1-9.

49. Yang X, Yu Y, Xu J, Shu H, Liu H, Wu Y, Zhang L, Yu Z, Fang M, Yu T, Wang Y. Clinical course and outcomes of critically ill patients with SARS-CoV-2 pneumonia in Wuhan, China: a single-centered retrospective, observational study. The Lancet Respiratory Medicine. 2020.

50. Guo YR, Cao QD, Hong ZS, Tan YY, Chen SD, Jin HJ, Tan KS, Wang DY, Yan Y. The origin, transmission and clinical therapies on coronavirus disease 2019 (COVID-19) outbreak-an update on the status. Military Medical Research. 2020; 7:1-0.

51. Ai S, Zhu G, Tian F, Li H, Gao Y, Wu Y, Liu Q, Lin H. Population movement, city closure and spatial transmission of the 2019-nCoV infection in China. medRxiv. 2020 Jan 1.

52. Song F, Shi N, Shan F, Zhang Z, Shen J, Lu H, Ling Y, Jiang Y, Shi Y. Emerging 2019 novel coronavirus (2019-nCoV) pneumonia. Radiology. 2020:200274.

53. Jin YH, Cai L, Cheng ZS, Cheng H, Deng T, Fan YP, Fang C, Huang D, Huang LQ, Huang $Q$, Han Y. A rapid advice guideline for the diagnosis and treatment of 2019 novel coronavirus (2019-nCoV) infected pneumonia (standard version). Military Medical Research. 2020; 7:4.

54. Yu F, Du L, Ojcius DM, Pan C, Jiang S. Measures for diagnosing and treating infections by a novel coronavirus responsible for a pneumonia outbreak originating in Wuhan, China. Microbes and infection. 2020 Feb 1.

55. Corman VM, Landt O, Kaiser M, Molenkamp R, Meijer A, Chu DK Bleicker T, Brünink S, Schneider J, Schmidt ML, Mulders DG: Detection of 2019 novel coronavirus (2019-nCoV) by real-time RT-PCR. Eurosurveillance 2020;25.1-8

56. Burki T. Outbreak of coronavirus disease 2019. The Lancet Infectious Diseases. 2020; 20:292-3.

57. Yan Y, Shin WI, Pang YX, Meng Y, Lai J, You C, Zhao H, Lester E, Wu T, Pang CH. The First 75 Days of Novel Coronavirus (SARS-CoV-2) Outbreak: Recent Advances, Prevention, and Treatment. International Journal of Environmental Research and Public Health. 2020; 17:2323.

58. Zhang W, Du RH, Li B, Zheng XS, Yang XL, Hu B, Wang YY, Xiao GF, Yan B, Shi ZL, Zhou P. Molecular and serological investigation of 2019-nCoV infected patients: implication of multiple shedding routes. Emerging microbes \& infections. 2020; 9:386-9.

59. Yang Y, Peng F, Wang R, Guan K, Jiang T, Xu G, Sun J, Chang C. The deadly coronaviruses: The 2003 SARS pandemic and the 2020 novel coronavirus epidemic in China. Journal of autoimmunity. 2020:102434.

60. Cao W, Liu X, Bai T, Fan H, Hong K, Song H, Han Y, Lin L, Ruan L, Li T. High-dose intravenous immunoglobulin as a therapeutic option for deteriorating patients with Coronavirus Disease 2019. InOpen Forum Infectious Diseases 2020: 7.

61. Lai CC, Shih TP, Ko WC, Tang HJ, Hsueh PR. Severe acute respiratory syndrome coronavirus 2 (SARS-CoV-2) and corona 
virus disease-2019 (COVID-19): the epidemic and the challenges. International journal of antimicrobial agents. 2020:105924.

62. C.N.H. Commission New Coronavirus Pneumonia Prevention and Control Program (fifth ed.), China National Health Commission, 2020, 2020.

63. Chang D, Xu H, Rebaza A, Sharma L, Cruz CS. Protecting healthcare workers from subclinical coronavirus infection. The Lancet Respiratory Medicine. 2020; 8:e13.

64. Cheung JC, Ho LT, Cheng JV, Cham EY, Lam KN. Staff safety during emergency airway management for COVID-19 in Hong Kong. The Lancet Respiratory Medicine. 2020.

65. Wax RS, Christian MD. Practical recommendations for critical care and anesthesiology teams caring for novel coronavirus (2019$\mathrm{nCoV}$ ) patients. Canadian Journal of Anesthesia/Journal canadien d'anesthésie. 2020:1-9.

66. Network AR. Brower RG, Matthay MA, Morris A, Schoenfeld D, Thompson BT, Wheeler A. Ventilation with lower tidal volumes as compared with traditional tidal volumes for acute lung injury and the acute respiratory distress syndrome. $\mathrm{N}$ engl J med. 2000; 342:1301-8.

67. ARDSnet. NIH NHLBI ARDS Clinical Network Mechanical Ventilation Protocol Summary., 2020.

68. Arabi YM, Alothman A, Balkhy HH, Al-Dawood A, AlJohani S, Al Harbi S, Kojan S, Al Jeraisy M, Deeb AM, Assiri AM, Al-Hameed F: Treatment of Middle East Respiratory Syndrome with a combination of lopinavir-ritonavir and interferon- $\beta 1 \mathrm{~b}$ (MIRACLE trial): study protocol for a randomized controlled trial Trials. 2018:81:18

69. Arabi YM, Mandourah Y, Al-Hameed F, Sindi AA, Almekhlafi GA, Hussein MA, Jose J, Pinto R, Al-Omari A, Kharaba A, Almotairi A: Corticosteroid therapy for critically ill patients with Middle East respiratory syndrome. American journal of respiratory and critical care medicine 2018; 197:757-67.

70. Chen ZM, Fu JF, Shu Q, Chen YH, Hua CZ, Li FB, Lin R, Tang LF, Wang TL, Wang W, Wang YS. Diagnosis and treatment recommendations for pediatric respiratory infection caused by the 2019 novel coronavirus. World Journal of Pediatrics. 2020:1-7.

71. Du L, He Y, Zhou Y, Liu S, Zheng BJ, Jiang S. The spike protein of SARS-CoV-a target for vaccine and therapeutic development. Nature Reviews Microbiology. 2009; 7:226-36.

72. Lu H. Drug treatment options for the 2019-new coronavirus (2019-nCoV). Bioscience trends. 2020 Feb 29; 14:69-71.

73. Yao X, Ye F, Zhang M, Cui C, Huang B, Niu P, Liu X, Zhao L, Dong E, Song C, Zhan S. In vitro antiviral activity and projection of optimized dosing design of hydroxychloroquine for the treatment of severe acute respiratory syndrome coronavirus 2 (SARS-CoV2). Clinical Infectious Diseases. 2020.

74. Colson P, Rolain JM, Lagier JC, Brouqui P, Raoult D. Chloroquine and hydroxychloroquine as available weapons to fight COVID-19. Int J Antimicrob Agents. 2020; 105932.

75. Cortegiani A, Ingoglia G, Ippolito M, Giarratano A, Einav S. A systematic review on the efficacy and safety of chloroquine for the treatment of COVID-19. Journal of critical care. 2020.

76. Liu J, Cao R, Xu M, Wang X, Zhang H, Hu H, Li Y, Hu Z, Zhong W, Wang M. Hydroxychloroquine, a less toxic derivative of chloroquine, is effective in inhibiting SARS-CoV-2 infection in vitro. Cell discovery. 2020; 6:1-4.

77. Gautret P, Lagier JC, Parola P, Meddeb L, Mailhe M, Doudier B, Courjon J, Giordanengo V, Vieira VE, Dupont HT, Honoré S. Hydroxychloroquine and azithromycin as a treatment of COVID19: results of an open-label non-randomized clinical trial. International Journal of Antimicrobial Agents. 2020:105949.

78. Xu K, Chen Y, Yuan J, Yi P, Ding C, Wu W, Li Y, Ni Q, Zhou R, Li X, Xu M. Clinical efficacy of Arbidol in patients with 2019 novel coronavirus-infected pneumonia: a retrospective cohort study.

79. Young BE, Ong SW, Kalimuddin S, Low JG, Tan SY, Loh J, Ng OT, Marimuthu K, Ang LW, Mak TM, Lau SK. Epidemiologic features and clinical course of patients infected with SARS-CoV-2 in Singapore. Jama. 2020

80. Chu CM, Cheng VC, Hung IF, Wong MM, Chan KH, Chan KS, Kao RY, Poon LL, Wong CL, Guan Y, Peiris JS. Role of lopinavir/ritonavir in the treatment of SARS: initial virological and clinical findings. Thorax. 2004; 59(3):252-6.

81. Cao B, Wang Y, Wen D, Liu W, Wang J, Fan G, Ruan L, Song B, Cai Y, Wei M, Li X: A trial of lopinavir-ritonavir in adults hospitalized with severe Covid-19. New England Journal of Medicine 2020.
82. Sheahan TP, Sims AC, Leist SR, Schäfer A, Won J, Brown AJ, Montgomery SA, Hogg A, Babusis D, Clarke MO, Spahn JE: Comparative therapeutic efficacy of remdesivir and combination lopinavir, ritonavir, and interferon beta against MERS-CoV. Nature Communications 2020; 11:1-4.

83. Agostini ML, Andres EL, Sims AC, Graham RL, Sheahan TP, Lu X, Smith EC, Case JB, Feng JY, Jordan R, Ray AS. Coronavirus susceptibility to the antiviral remdesivir (GS-5734) is mediated by the viral polymerase and the proofreading exoribonuclease. MBio. 2018; 9:e00221-18.

84. Furuta Y, Komeno T, Nakamura T. Favipiravir (T-705), a broad spectrum inhibitor of viral RNA polymerase. Proceedings of the Japan Academy, Series B. 2017 Aug 2; 93(7):449-63.

85. Wang C, Li W, Drabek D, Okba NM, van Haperen R, Osterhaus AD, van Kuppeveld FJ, Haagmans BL, Grosveld F, Bosch BJ. A human monoclonal 1 antibody blocking SARS-CoV-2 infection. Biorxiv. 2020.

86. Xu X, Han M, Li T, Sun W, Wang D, Fu B, Zhou Y, Zheng X, Yang Y, Li $X$, Zhang X. Effective treatment of severe COVID-19 patients with Tocilizumab. ChinaXiv. 2020; 202003:v1.

87. Zhang H, Baker A. Recombinant human ACE2: acing out angiotensin II in ARDS therapy. Critical Care. 2017; 21.30-36

88. Casadevall A, Pirofski LA. The convalescent sera option for containing COVID-19. The Journal of clinical investigation. 2020; $130(4)$.

89. Cheng VC, Lau SK, Woo PC, Yuen KY. Severe acute respiratory syndrome coronavirus as an agent of emerging and reemerging infection. Clinical microbiology reviews. 2007; 20:660-94.

90. Loutfy MR, Blatt LM, Siminovitch KA, Ward S, Wolff B, Lho H, Pham DH, Deif H, LaMere EA, Chang M, Kain KC. Interferon alfacon-1 plus corticosteroids in severe acute respiratory syndrome: a preliminary study. Jama. 2003; 290:3222-8.

91. Mustafa S, Balkhy H, Gabere MN. Current treatment options and the role of peptides as potential therapeutic components for Middle East Respiratory Syndrome (MERS): a review. Journal of infection and public health. 2018; 11:9-17.

92. Gilardin L, Bayry J, Kaveri SV. Intravenous immunoglobulin as clinical immune-modulating therapy. Cmaj. 2015; 187:257-64.

93. Kumar V, Jung YS, Liang PH. Anti-SARS coronavirus agents: a patent review (2008-present). Expert opinion on therapeutic patents. 2013; 23:1337-48.

94. Nicastri E, Petrosillo N, Bartoli TA, Lepore L, Mondi A, Palmieri F, D’Offizi G, Marchioni L, Murachelli S, Ippolito G, Antinori A. National Institute for the Infectious Diseases "L. Spallanzani", IRCCS. Recommendations for COVID-19 clinical management. Infectious Disease Reports. 2020; 12.

95. Mair-Jenkins J, Saavedra-Campos M, Baillie JK, Cleary P, Khaw FM, Lim WS, Makki S, Rooney KD, Convalescent Plasma Study Group, Nguyen-Van-Tam JS, Beck CR: The effectiveness of convalescent plasma and hyperimmune immunoglobulin for the treatment of severe acute respiratory infections of viral etiology: a systematic review and exploratory meta-analysis. The Journal of infectious diseases 2015; 211:80-90

96. Klimpel GR. Immune defenses. InMedical Microbiology. 4th edition 1996. University of Texas Medical Branch at Galveston.

97. Zumla A, Chan JF, Azhar EI, Hui DS, Yuen KY: Coronaviruses-drug discovery and therapeutic options. Nature reviews Drug discovery 2016; 15:327.

98. Abdullah AS, Tomlinson B, Cockram CS, Thomas GN. Lessons from the severe acute respiratory syndrome outbreak in Hong Kong. Emerging Infectious Diseases. 2003; 9:1042.

99. Wenzel RP, Edmond MB. Listening to SARS: lessons for infection control. Annals of internal medicine. 2003; 139:592-3

100. Cheng VC, Chan JF, To KK, Yuen KY. Clinical management and infection control of SARS: lessons learned. Antiviral research. 2013; 100:407-19.

101. Parashar UD, Anderson LJ. Severe acute respiratory syndrome: review and lessons of the 2003 outbreak. Int. J. Epidemiol., 2004;33: 628-634

102. Pang X, Zhu Z, Xu F, Guo J, Gong X, Liu D, Liu Z, Chin DP, Feikin DR. Evaluation of control measures implemented in the severe acute respiratory syndrome outbreak in Beijing, 2003. Jama. 2003; 290:3215-21. 